\title{
MODIFIKASI IRC3 (INTRODUCE, REVIEW, COMPARE, CONCLUSION, CREATIVE) DI IAI AI-MAWADDAH WARRAHMAH KOLAKA
}

\author{
Nur Thahirah Umajjah \\ Dosen IAI Al-Mawaddah Warrahmah Kolaka \\ Email: iranurthahira@gmail.com
}

Diterima Tangal: 20 April 2019

Selesai Tanggal 26 Mei 2019

\begin{abstract}
IAI Al-Mawaddah Warrahmah Kolaka is one of the PTKIS (private Islamic college) in the Kolaka district, which shows an increase in the number of students each year, so the learning system needs to improve to produce qualified alumnies. This study aims to determine the application and results of the IRC3 Modified Research-Based Learning Model (Introduce, Review, Compare, Conclusion, and Creative) in Kolaka's IAI Al-Mawaddah Warrahmah in terms of student responses. This research was conducted for 4 months in the fourth semester students of the PAI Department of learning media courses. The type of research used is descriptive research. The conclusions from the results of this study indicate that the application of IRC3 modification research based learning in Kolaka IAI Al Mawaddah Warrahmah is done in 5 Steps, namely: (Introduce, Review, Compare, Conclusion, Creative) and the final result of implementing this learning model is the student's creative work in the form of research journals. The application of IRC3 modification research based learning models received positive responses from all students.
\end{abstract}

[IAI Al-Mawaddah Warrahmah Kolaka adalah salah satu PTKIS di wilayah kabupaten Kolaka, yang menunjukkan peningkatan jumlah mahasiswa di tiap tahunnya, sehingga sistem pembelajaran perlu diperhitungkan untuk menghasilkan alumni yang unggul dalam kualitas. Penelitian ini bertujuan untuk mengetahui penerapan dan hasil atas Model Pembelajaran Berbasis Riset Modifikasi IRC3 (Introduce, Review, Compare, Conclusion, Creative) di IAI Al-Mawaddah Warrahmah Kolaka ditinjau dari respon mahasiswa. Penelitian ini dilakukan selama 4 bulan pada mahasiswa semester IV Jurusan PAI mata kuliah media pembelajaran. Jenis penelitian yang digunakan adalah penelitian deskriptif. Kesimpulan dari hasil penelitian ini menunjukkan bahwa penerapan pembelajaran berbasis riset modifikasi IRC3 di IAI Al Mawaddah Warrahmah Kolaka dilakukan dengan 5 Langkah yaitu: (Introduce, Review, Compare, Conclusion, Creative) dan hasil akhir dari penerapan model pembelajaran ini adalah karya kreatifitas mahasiswa yang dituangkan dalam bentuk jurnal hasil penelitian. Penerapan model pembelajaran berbasis riset modifikasi IRC3 mendapat tanggapan positif dari seluruh mahasiswa].

Kata Kunci: Pembelajaran berbasis riset; Modifikasi IRC3; IAI Kolaka

\section{PENDAHULUAN}

Pendidikan adalah setiap usaha, pengaruh, perlindungan dan bantuan yang diberikan kepada anak tertuju kepada pendewasaan anak itu, atau lebih tepat membantu anak agar cukup cakap melaksanakan tugas hidupnya sendiri. Pengaruh itu datangnya dari orang dewasa 
(atau yang diciptakan oleh orang dewasa seperti sekolah, buku, putaran hidup sehari-hari, dan sebagainya) dan ditujukan kepada orang yang belum dewasa ${ }^{1}$

Jantung dalam suatu pendidikan adalah proses pembelajaran. Kualitas pembelajaran bersifat kompleks dan dinamis, dapat dipandang dari berbagai persepsi dan sudut pandang melintasi garis waktu. Pada tingkat mikro, pencapaian kualitas proses pembelajaran merupakan tanggungjawab profesional seorang pendidik, misalnya melalui penciptaan pengalaman belajar yang bermakna bagi peserta didik dan fasilitas yang didapat peserta didik untuk mencapai hasil belajar yang maksimal. Pada tingkat makro, melalui sistem pembelajaran yang berkualitas, lembaga pendidikan bertanggungjawab terhadap pembentukan tenaga pengajar yang berkualitas, yaitu yang dapat berkontribusi terhadap perkembangan intelektual, sikap, dan moral dari setiap individu peserta didik sebagai anggota masyarakat.

Institut Agama Islam AlMawaddah Warrahmah Kolaka adalah salah satu perguruan tinggi swasta yang berdedikasi untuk pengembangan dunia pendidikan. Berdasarkan data statistik, tiap tahunnya mengalami peningkatan untuk

1 Sanjaya, Strategi Pembelajaran Berorientasi Standar Proses Pendidikan (Jakarta: Kencana Prenada Media, 2011), hlm. 2. peminatan mahasiswa dalam mengenyam pendidikan strata satu (S1) di institut tersebut. Oleh karena itu, sangat penting untuk mempertimbangkan sisi kualitas output mahasiswa yang tentunya di backup oleh sistem pembelajaran yang ada didalamnya.

Hasil observasi awal menunjukkan bahwa proses pembelajaran yang diterapkan mayoritas masih bersifat konvensional. Konvensional yang dimaksud adalah sistem pembuatan makalah. Dalam proses pembelajaran ini, mahasiswa di bagi kedalam beberapa kelompok, dan masing-masing kelompok akan mempresentasikan makalah sesuai dengan materi yang dibebankan kepadanya. Kemudian beberapa mahasiswa memberikan tanggapan, pertanyaan, dan masukan. Akhir dari proses pembelajaran, dosen memberikan kesimpulan dan penguatan perihal materi yang telah dibahas oleh kelompok yang telah mepresentasikan makalahnya.

Peneliti yang pada dasarnya adalah dosen media pembelajaran di Fakultas Tarbiyah dan Keguruan mencoba menganalisis hasil dari proses pembelajaran konvensional tersebut. Hasil analisis menunjukkan bahwa proses pembelajaran konvensional kurang efektif, khususnya pada mata kuliah media pembelajaran. Sebab, model pembelajaran 
konvensional kurang memberikan umpan balik kepada mahasiswa dalam melatih kemampuan berpikir kritis, berinovasi, dan berkreasi. Padahal saat ini, sistem pembelajaran disemua tingkatan menuntut dilatihnya HOTS (Higher Order Thinking Skill).

Lebih dari pada itu, pada saat diajukan pertanyaan kepada mahasiswa Pendidikan Agama Islam (PAI) Semester IV perihal budaya literasi ilmiah, sangat minim yang mengetahui cara mengakses reverensi bacaan yang dapat dipertanggungjawabkan. Kebanyakan di antara mereka membuat makalah berdasarkan hasil penulusuran internet dengan tidak memperhatikan sumbernya. Padahal seyogyanya mereka sudah wajib berada dilevel tingkat atas yang mampu menyaring sumber pengetahuan ilmiah secara benar.

Berdasarkan uraian permasalahan diatas peneliti mencoba untuk melakukan sebuah penelitian dengan menerapkan Model Pembelajaran Berbasis Riset Modifikasi IRC3 (Introduce, Review, Compare, Conclusion, Creative) Di IAI Al-Mawaddah Warrahmah Kolaka sebagai strategi dan solusi dalam pengembangan dan peningkatan kualitas mutu pembelajaran. Dalam penelitian ini, difokuskan pada kajian masalah (1) Penerapan Model Pembelajaran Berbasis
Riset Modifikasi IRC3 (Introduce, Review, Compare, Conclusion, Creative) Di IAI Al-Mawaddah Warrahmah Kolaka, (2) Hasil Penerapan Model Pembelajaran Berbasis Riset Modifikasi IRC3 (Introduce, Review, Compare, Conclusion, Creative) Di IAI Al-Mawaddah Warrahmah Kolaka ditinjau dari respon mahasiswa.

\section{PEMBAHASAN}

Penerapan sistem pembelajaran ini didukung oleh beberapa teori bahkan beberapa universitas terkemuka yang telah menerapkan sistem pembelajaran tersebut. Konsep universitas sebagai lembaga riset muncul pada abad ke-19 di Jerman, di saat Revolusi Industri mulai menguasai dunia dan di era ledakan ide-ide baru. Munculnya ide-ide dan teknologi baru tersebut membutuhkan penelitian empiris di laboratorium untuk menguji keabsahannya agar dapat dikembangkan lebih luas. Keunggulan aspek penelitian dibanding pengajaran ditunjukkan pada tipe universitas versi Humboldtian yang menekankan bahwa perjalanan mengejar ilmu pengetahuan selayaknya perjalanan perusahaan. Aspek yang dapat dilihat dari universitas modern adalah adanya 
ketentuan pendanaan dari masyarakat dan pemerintah untuk mendukung penelitian ${ }^{2}$

Universitas sains dan teknologi di hongkong HKUST adalah universitas berbasis riset yang sangat berkembang pesat. Terbukti dengan keluaran outputnya yang mampu bersaing dalam dunia kerja. Lebih dari pada itu beberapa prestasi sebagai salah satu universitas terbaik dalam survey internasional sering kali diraih oleh universitas tersebut misalnya peringkat 39 dalam 100 universitas terbaik di bidang teknik dan teknologi serta komputer sains (peringkat 1 di "Greater China") pada tahun 2010 dan (e) peringkat 52-57 dalam 100 universitas terbaik di dunia dalam bidang ilmu sosial (peringkat 1 di "Greater China") pada tahun 2010 (Philip, 2012; 61). Selanjutnya, sebuah universitas riset swasta kelas dunia di pingiiran yaitu universitas sains dan teknologi Pohang (POSTECH) Republik Korea Selatan. Keunikan POSTECH yaitu kemampuannya mencapai status kelas dunia hanya dalam tahap dua Dekade saja ${ }^{3}$

Penelitian serupa juga dilakukan oleh Ahmad Nizar Rangkuti seorang mahasiswa pendidikan matematika IAIN Padangsidimpuan. Hasil penelitiannya menujukkan bahwa budaya melakukan

\footnotetext{
${ }^{2}$ Philip G. Altbach, Jamil Salmi, The Road to Academic Excellence (Jakarta: Salemba Humanika, 2011), hlm. 4.

${ }^{3}$ Philip G. Altbach, Jamil Salmi, The Road to Academic ..., hlm. 99
}

riset dapat dijadikan sebagai salah satu indikator keberhasilan suatu universitas berbasis riset. Pembelajaran berbasis riset merupakan metode pembelajaran yang menggunakan pembelajaran autentik, pemecahan masalah, pembelajaran kooperatif, pembelajaran kontekstual, dan pendekatan inquiri yang dipandu oleh filsafat konstruktivisme. Pembelajaran berbasis riset ini dapat mengubah fokus pembelajaran dari penghafalan konsepkonsep dan fakta-fakta ke dalam belajar berdasar inkuiri. Pembelajaran berbasis riset dibangun berdasarkan pada sintesis beberapa teori belajar yang telah berkembang sebelumnya. Teori belajar yang dimaksudkan adalah teori behaviorisme, teori kognitivisme, dan teori konstruktivisme. Pembelajaran berbasis riset dapat memberi kontribusi terhadap pertumbuhan keterampilan mahasiswa dalam melakukan penelitian.

Berdasarkan pemaparan keberhasilan perguruan tinggi berbasis riset di atas, maka penerapan model pembelajaran berbasis riset sangat efektif diterapkan pada proses pembelajaran khususnya pada wilayah perguruan tinggi. Sebab, dengan penerapan model pembelajaran tersebut, maka tentunya akan menghasilkan lulusan yang berkualitas, berdaya saing tinggi, karena kemampuan berpikir kritis, 
melakukan kreasi dan inovasi telah ditanamkan sejak dini.

Pembelajaran berbasis riset merupakan salah satu metode yang mengintegrasikan riset di dalam proses pembelajaran. Beberapa model pembelajaran berbasis riset antara lain:

a. Memperluas bahan ajar dengan hasil penelitian dosen;

b. Memanfaatkan penelitian mutakhir dan melacak sejarah ditemukannya perkembangan mutakhir tersebut;

c. Melakukan kegiatan pembelajaran dengan isu penelitian kontemporer;

d. Memberikan materi metodologi penelitian di dalam proses pembelajaran;

e. Memformulasikan proses pembelajaran dengan melibatkan mahasiswa dalam kegiatan penelitian. ${ }^{4}$

Pada penelitian ini diterapkan Model Pembelajaran Berbasis Riset Modifikasi IRC3 (Introduce, Review, Compare, Conclusion, Creative) Di IAI Al-Mawaddah Warrahmah Kolaka tepatnya pada mata kuliah "Media Pembelajaran" mahasiswa Pendidikan Agama Islam (PAI) semester IV T.A 20172018. Penelitian ini dilakukan kurang lebih

${ }^{4}$ Saide, "Perguruan Tinggi Islam Berbasis Riset Menyongsong Bonus Demografi Indonesia 2045", Al-Hikmah: Jurnal Dakwah, Vol. 12, No. 1, Tahun 2018, [Pp. 122-130], hlm. 126. selama 4 bulan dengan jenis penelitian deskriptif dengan pendekatan kualitatif. Dimana penelitian ini menggambarkan secara deskriptif kualitatif model pembelajaran berbasis riset yang dimodifikasi kedalam 5 langkah utama pembelajaran yaitu (Introduce, Review, Compare, Conclusion, Creative).

Model Pembelajaran Berbasis Riset Modifikasi IRC3 (Introduce, Review, Compare, Conclusion, Creative) adalah model pembelajaran berbasis riset yang dimodifikasi dengan 5 langkah utama pembelajaran yang diuraikan sebagai berikut ${ }^{5}$ :

1. Introduce memiliki makna (memperkenalkan).

Introduce merupakan langkah awal dari model pembelajaran berbasis riset modifikasi IRC3. Dimana pada tahap ini mahasiswa diperkenalkan secara garis besar mengenai materi yang akan dibahas. Selain itu juga, mahasiswa diberikan arahan mengenai fokus kajian materi yang akan dibahas.

Penelitian ini dilakukan pada mata kuliah media pembelajaran. Oleh karena itu, pada langkah ini mahasiswa diperkenalkan materi media pembelajaran yang akan dibahas selama proses

5 Echols, John M, Kamus Inggris Indonesia (Jakarta: PT Gramedia Pustaka Utama, 1996), hlm. 132-484. 
perkuliahan. Materi tersebut di antaranya adalah (Media pembelajaran berbasis computer pada multimedia dan presentasi pada program PPT dan Prezy, Media pembelajaran berbasis computer model simulasi pada program Macromedia Flash, Media pembelajaran berbasis computer web/internet pada program Quipper, Media pembelajaran berbasis computer web/internet jarak jauh pada program Edmodo, Penerapan Media Evaluasi Pemeblajaran Peserta didik Berbasis Internet pada program Zipgrade, Penerapan Media Evaluasi Pemeblajaran Peserta didik Berbasis Internet pada program Plickers, Penerapan Media Pembelajaran PAI Sederhana Ramah Lingkungan).

2. Review memiliki makna (Meninjau, Resensi, memberikan tinjauan) memiliki padanan kata to write.

Review merupakan langkah kedua dari proses pembelajaran berbasis riset modifikasi IRC3. Pada langkah ini mahasiswa terlebih dahulu mengulas atau meninjau materi yang akan dibahas pada saat perkuliahan. Sehingga pada saat perkuliahan berlangsung mereka telah memiliki pengetahuan dasar mengenai materi yang akan dibahas. Pada tahap ini mahasiswa wajib mengulas minimal 5 jurnal penelitian dan 3 buku yang terkait dengan materi perkuliahan yang akan dibahas. Sehingga pada saat perkuliahan berlangsung, dosen terlebih dahulu mengecek hasil review dari mahasiswa mengenai materi yang akan dibahas. Dosen melakukan cek hasil review dengan memberikan pertanyaan perihal materi yang akan dibahas. Selain itu, dosen juga meminta mahasiswa untuk memberikan tanggapan dari beberapa jurnal hasil penelitian yang telah mereka review.

3. Compare memiliki makna (Membandingkan).

Compare adalah langkah ketiga dari proses pembelajaran berbasis riset modifikasi IRC3. Kegiatan ini juga dilakukan diluar proses perkuliahan. Pada tahap ini mahasiswa melakukan perbandingan antara referensi secara teoretik dan aplikasi dilapangan. Misalnya materi yang akan dibahas pada perkuliahan selanjutnya adalah "Media Pembelajaran Edmodo", maka mahasiswa setelah mengulas referensi dan hasil riset sebelumnya tentang penerapan media pembelajaran edmodo, harus melakukan studi perbandingan dengan media pembelajaran edmodo yang sesungguhnya. Pada langkah ini juga mahasiswa mengoperasikan secara mandiri media pembelajaran yang akan dibahas pada pertemuan diperkuliahan 
nanti. Sehingga, pada akhirnya mahasiswa akan membandingkan apakah hasil penelitian dan beberapa referensi yang telah diulas sejalan dengan media pembelajaran yang sesungguhnya. Hasil dari perbandingan tersebut, dicatat kemudian jika ada halhal yang kurang dipahami akan dibahas pada saat perkuliahan berlangsung.

4. Conclusions memiliki makna (Penarikan Kesimpulan)

Conclusions adalah langkah terakhir dari model pembelajaran berbasis riset modifikasi IRC3 yang dilakukan secara berkala pada tiap pertemuan perkuliahan. Pada tahap ini mahasiswa mengambil kesimpulan dari hasil perbandingan teori yang telah dikaji dan media pembelajaran yang telah dioperasikan secara mandiri. Pada langkah ini juga mahasiswa melakukan sharing diskusi pada saat perkuliahan mengenai hal yang mereka temukan selama proses review dan compare materi. Selain itu, pada tahap ini dosen menjadi fasilitator jika ada hambatan pemahaman mahasiswa selama proses review dan compare materi. Sehingga proses perkuliahan berjalan secara aktif dan disuguhi dengan diskusi dari beberapa pengalaman mahasiswa selama proses review dan compare materi.
5. Creative (Berkreasi)

Creative (Berkreasi) adalah tahap akhir sekaligus evaluasi dari model pembelajaran berbasis riset modifikasi IRC3. Tahap ini adalah tahap dimana mahasiswa menerapkan pengetahuan yang diperoleh selama proses pembelajaran. Pada tahap ini mahasiswa turun kelapangan untuk melakukan sebuah penelitian dengan menerapkan media pembelajaran yang telah dibahas pada saat perkuliahan. Pada penelitian ini, mahasiswa turun kelapangan sesuai dengan sekolah yang telah dipilih, kemudian mereka menganalisis kondisi lingkungan sekolah, siswa, guru, serta materi ajar, yang kemudian menjadi bahan pertimbangan bagi mereka dalam melakukan sebuah penelitian dengan menerapkan media pembelajaran yang tepat sesuai hasil analisis awal.

Hasil pada tahap ini yaitu mahasiswa membuat media pembelajaran dan melakukan penelitian dengan menerapkan media pembelajaran tersebut. Kemudian menuangkan hasil penelitian tersebut ke dalam jurnal penelitian. 3 jurnal penelitian masing-masing kelompok mahasiswa telah diterbitkan di jurnal elektronik Institut Agama Islam Al Mawaddah Warrahmah Kolaka. Jurnal 
tersebut dapat diakses pada halaman web "Journal.iaialmawar.ac.id".

Lima langkah di atas di dasari pada teori pembelajaran berbasis riset (PBR) yang merupakan salah satu metode student-centered learning (SCL) yang mengintegrasikan riset di dalam proses pembelajaran. PBR bersifat multifaset yang mengacu kepada berbagai macam metode pembelajaran. PBR memberi peluang/kesempatan kepada mahasiswa untuk mencari informasi, menyusun hipotesis, mengumpulkan data, menganalisis data, dan membuat kesimpulan atas data yang sudah tersusun; dalam aktivitas ini berlaku pembelajaran dengan pendekatan "learning by doing" dengan metode sebagai berikut: 1) memperkaya bahan ajar dengan hasil penelitian dosen; 2) menggunakan temuantemuan penelitian mutakhir dan melacak sejarah; 3) memperkaya kegiatan pembelajaran dengan isu-isu penelitian kontemporer; 4) mengajarkan materi metodologi penelitian di dalam proses pembelajaran; 5) memperkaya proses pembelajaran dengan kegiatan penelitian dalam skala kecil; 6) memperkaya proses pembelajaran dengan melibatkan peserta didik dalam; 7) memperkaya proses pembelajaran dengan mendorong peserta; 8) memperkaya proses pembelajaran dengan nilai-nilai yang harus dimiliki oleh peneliti ${ }^{6}$

Selain itu, salah satu model pembelajaran berbasis riset yang menggunakan strategi pertama, yaitu "Memperkaya bahan ajar dengan hasil penelitian dosen”. Pada strtegi ini, pada pembelajaran ini hal-hal pokok yang harus dilakukan oleh dosen adalah sebagai berikut. Pada kegiatan persiapan; (1) melakukan pengecekan kehadirian, (2) melakukan apersepsi, dan menyampaikan tujuan pembelajaran. Pada tahapan ini pembelajaran lebih didominasi oleh dosen, namun tetap diperhatikan bahwa kegiatan dosen sedapat mungkin diiringi oleh kegiatan mahasiswa. Informasi yang disampaikan dosen, hendaknya direspon oleh mahasiswa. Misalnya saat dosen mengecek kehadiran maka semua mahasiswa ikut terlibat aktif ${ }^{7}$ Tahapan kedua adalah kegiatan inti. Pada tahapan ini dosen melakukan kegiatan-kegiatan sebagai berikut, (1) memberikan informasi pokok tenang materi yang sedang dipelajari, menunjukkan hasil-hasil penelitian dosen yang berkenaan/bersentuhan dengan materi

\footnotetext{
6 Tim Penyusun, Pedoman Umum Pembelajaran Berbasis Riset (Yogyakarta: Universitas Gadjah Mada, 2010).

7 Kudrat, Pengembangan Pembelajaran Berbasis Riset Di Program Studi Pendidikan Fisika FMIPA Universitas Negeri Gorontalo (Laporan Penelitian), (Gorontalo: Universitas Negeri Gorontalo, 2011), hlm. 32.
} 
yang sedang dibahas, (3) membagi mahasiswa dalam kelompok diskusi, (4) memberikan penugasan kepada mahasiswa dalam bentuk diskusi dalam kelompokkelompok tentang (a) isi pokok penelitian, (b) proses penelitian, (c) cara analisis, (d) perumusan kesimpulan, dan (e) nilai-nilai yang muncul dari hasil penelitian terseut, (4) dengan dipimpin dosen mahasiswa melakukan diskusi antar kelompok, (5) bersama dosen mahasiswa membuat kesimpulan. Dalam tahapan ini sedapat mungkin mahasiswa lebih terlibat dalam pembelaaran (pembelajaran berpusat pada mahasiswa). Dosen lebih berperan sebagai fasilitator. Bila memungkinkan saat diskusi berlangsung, apabila terdapat persoalanpersoalan yang membutuhkan literatur, dosen dapat menunjukkannya melalui media online (internet) sehingga problematika yang dihadapi mahasiswa dapat terjawab ${ }^{8}$.

Tahapan ketiga adalah, penutup. Pada tahapan ini dosen menyampaikan kembali pokok-pokok kesimpulan materi serta menyampaikan penugasanpenugaasan yang harus dikerjakan mahasiswa. Penugasan hendaknya melibatkan sumber belajar berupa hasil-hasil riset dalam menyelesaikannya 9 .

8 Kudrat, Pengembangan Pembelajaran Berbasis..., hlm. 32-33.

9 Kudrat, Pengembangan Pembelajaran Berbasis..., hlm. 33.
Pada penelitian ini dilakukan wawancara dengan mahasiswa mengenai langkah-langkah penerapan pembelajaran berbasis riset pada tanggal 2 Oktober 2018 . Muh irfan memberi keterangan mengenai langkah-langkah model pembelajaran ini bahwa:

"Model pembelajaran berbasis riset modifikasi IRC3 telah diterapkan sejak awal pada mata kuliah media pembelajaran disemester IV oleh dosen mata kuliah media pembelajaran. Sebelumnya beliau telah mengajar kami pada mata kuliah ilmu alamiah dasar. Dari itulah beliau mencoba melakukan modifikasi model pembelajaran berbasis riset modifikasi IRC3. Pada penerapannya, model pembelajaran ini diawali dengan memperkenalkan kepada mahasiswa seputar materi yang akan dibahas. Selanjutnya mahasiswa secara mandiri melakukan kajian terhadap beberapa hasil riset yang telah ada mengenai materi yang akan dibahas. Kemudian, mahasiswa mengoperasikan secara mandiri media pembelajaran yang akan dibahas agar dapat membandingkan teori dan aplikasi sesungguhnya, dari hasil perbandingan teori dan praktek tersebut, mahasiswa mengambil kesimpulan mengenai materi yang akan dibahas, dan pada pertengahan semsester mahasiswa melakukan riset sederhana perihal penerapan media pembelajaran pada sekolah yang telah di observasi awal sebelumnya".

Keterangan serupa diungkapkan oleh Kamiliah Rahmah seorang mahasiswi PAI semester IV yaitu: 
"Penerapan pembelajaran berbasis riset modifikasi IRC3 ini diterapkan pada mata kuliah media pembelajaran. Dalam penerapannya, mahasiswa dilatih secara mandiri untuk melakukan literasi ilmiah sejak dini. Jadi langkah awalnya adalah dosen memperkenalkan materi media pembelajaran yang akan dibahas, selanjutnya mahasiswa mengkaji riset perihal materi tersebut, kemudian secara mandiri mengoperasikan media pembelajaran, dan selanjutnya membandingkan bagaiamna hasil riset dengan media yang sesungguhnya, lalu menga,mbil kesimpulan. Apabila ada hal-hal yang kurang dipahami, maka semuanya akan dibahas pada saat perkuliahan berlangsung. Output dari mata kuliah ini adalah mahasiswa mampu melakukan penelitian ilmiah di SDIT Al-Mawar Kolaka dengan menerapkan media pembelajaran sesua dengan hasil analisis siswa, kondisi lingkungan sekolah dan wawancara terhadap guru disekolah tersebut. Hasil karya tulis mahasiswa juga telah diterbitkan pada jurnal elektronikm PT IAI Al Mawaddah Warrahmah Kolaka”.

Selanjutnya dilakukan wawancara lanjutan pada mahasiswa atas nama Suci Cahyani, dalam penjelasannya dia memaparkan bahwa:

"Pembelajaran berbasis riset diterapkan pada awal materi perkuliahanm yang dijelaskan pada saat kontrak perkuliahan oleh dosen. Pada konrak perkuliahan, dosen memaparkan bahwa sistem pembelajaran yang akan diterapkan adalah sistem pembelajaran berbasis riset. Dimana langkah awalnya adalah memperkenalkan media pembelajaran yang akan dibahas secara garis besar. Selanjutnya mahasiswa secara mandiri mengkaji materi tersebut sebelum masuk perkuliahan. Cara mengkaji materi yaitu dengan mengulas jurnal hasil penelitian minimal 5 dan mengulas referensi buku sesuai materi minimal 3 . Selanjutnya, kami membandingkan antara referensi yang telah kami kaji dengan media pembelajaran yang sebenanrya, dengan cara mengoperasikan media tersebut secara mandiri. Kemudian kami mencatat kendala yang kami dapatka, yang selanjutnya akan didiskusikan pada saat pertemuan diperkuliahan. Akhir dari proses pembelajaran ini, yaitu pada pertengahan semester kami mulai terjun kelapangan untuk meneliti dengan menerapkan media pembelajaran sesuai dengan analisis dan observasi awal kami disekolah tersebut. Dan hasil penelitian itu telah diterbitkan dalam jurnal Teknologi Pendidikan di IAI Al Mawdah Warrahmah Kolaka”.

Dari pemaparan diatas, jelas bahwa 5 langkah utama pembelajaran berbasis riset modifikasi IRC3 yaitu (Introduce, Review, Compare, Conclusion, Creative). Langkah awal adalah memperkenalkan kepada mahasiswa secara garis besar materi yang akan dibahas. Selanjutnya mahasiswa mengkaji materi yang akan dibahas melalui hasil riset. Kemudian membandingkan hasil riset dengan aplikasi yang sesungguhnya, dari itulah mahasiswa 
akan mengambil kesimpulan. Jika dalam proses tersebut mereka menemukan kendala, maka akan dibahas pada saat perkuliahan berlangsung. Output akhir dari pembelajaran ini adalah mahasiswa melakukan sebuah penelitian dengan menerapkan media pembelajaran yang telah dipelajari dengan pertimbangan hasil analisis dan observasi awal pada sekolah yang menjadi lokasi penelitian. Hasil penelitian tersebut kemudian dipublikasikan pada jurnal teknologi pendidikan IAI Al Mawaddah Warrahmah Kolaka.

Adapun hasil penerapan model pembelajaran berbasis riset modifikasi IRC3 ini ditinjau dari respon mahasiswa bernilai positif. Analisis ini dilakukan dengan membagikan angket terbuka kepada mahasiswa PAI semester IV sebanyak 15 orang. Selain itu, dilakukan pula wawancara terstruktur kepada 4 orang mahasiswa PAI semester IV. Hasil analisis angket tersebut secara garis besar, menggambarkan respon positif mahasiswa terhadap penerapan model pembelajaran modifikasi IRC3. Hasil analisis pengisian angket terbuka pada tanggal 25 september 2018 Salah satu mahasiswa atas nama Hikmawati memberikan tanggapan bahwa:

"Menurut saya, model pembelajaran berbasis riset modifikasi IRC3 ini sangat banyak manfaatnya, terutama dalam meningkatkan kepercayaan diri mahasiswa, menuangkan pendapat, dan dalam berlatih karya tulis ilmiah. Sebab awalnya saya tidak mengetahu cara dalam penulisan karya tulis ilmiah, tapi dengan diterapkannya sistem pembelajaran ini, maka saya mampu melakukan sebuah penelitian dan menungkan hasil penelitian tersebut dalam jurnal pendidikan. Selain itu, manfaat lain yang saya rasakan adalah dapat meningkatkan wawasan ilmiah".

Selain itu, pendapat dari mahasiswa lain atas nama Annisa, dalam keterangannya bahwa:

"Model pembelajaran berbasis riset modifikasi IRC3 sangat bermanfaat, sebab model pembelajaran ini membiasakan mahasiswa mencari informasi secara mandiri dan ilmiah, sehingga mampu meningkatkan kecakapan berpikir. Karena awalnya, saya sangat jarang membaxa artikel ataupun jurnal ilmiah hasil penelitian yang telah ada. Namun dengan diterapkannya sistem pembelajaran ini, maka awalnya saya merasa agak berat untuk mengkaji hasil riset, namun seiring berjalannya waktu, saya menjadi terbiasa dan sangat merasakan manfaatnya. Selain itu, penerapan model pembelajaran ini memberikan kesempatan lebih banyak kepada mahasiswa untuk meningkatkan pengetahuan secara mandiri, sehingga mampu meningkatkan minat belajar dan motivasi belajar".

Pendapat lain dari seorang mahasiswa atas nama Muh.Faisal Syam mengungkapkan bahwa: 
"Model pembelajaran berbasis riset modifikasi IRC3 mampu melatih sikap tanggungjawab mahasiswa, sebab memberikan kepercayaan kepada mahasiswa dalam mengakji teori dan aplikasi secara mandiri, yang kemudian dipertanggungjawabkan pada diskusi ketika perkuliahan berlangsung".

Dari hasil wawancara pada tanggal

2 Oktober 2018 bersama Kamiliah

Rahmah yang merupakan salah satu mahaiswi PAI semester IV menyatakan bahwa:

"Penerapan pembelajaran berbasis riset modifikasi IRC3 sangat memberikan manfaat bagi mahasiswa. Meskipu di awalnya kami sangat kewalahan, sebab kami harus mengkaji minimal 5 jurnal penelitian dan 3 referensi buku yang terkait dengan materi yang akan dibahas. Namun berlanjut beberapa kali pertemuan, kami telah terbiasa, dan sangat merasakan manfaatnya. Yang awalnya kami tidak pernah membaca jurnal penelitian pada akses web google scholar, akhirnya menjadi salah satu referensi kami. Dari ini juga kami mengetahui bahwa sanya dalam mengambil kutipan di internet, harus pada web yang dipercaya, kredibilitas, dan akuntabilitas".

Pandangan lain dari salah satu mahasiswa PAI semester IV atas nama Amelia, mengungkapkan bahwa:

"Dengan diterapkannya pembelajaran berbasis riset modifikasi IRC3 sangat membantu saya dalam melatih kemamndirian mengkaji teori media pembelajaran. Selain itu juga, mampu membuat kami kompak dalam berdiskusi perihal materi yang akan dibahas. Bahkan pada saat kuliah berlangsung, kami saling share perihal apa yang kami dapatkan pada saat mengkaji materi yang akan dibahas, sehingga dalam perkuliahan keaktifan mahasiswa sangat terlihat jelas. Dosen pun menjadi fasilitaor sekaligus penengah jika ada kendala atau hal yang masih membingungkan khususnya dalam mengaplikasikan media pembelajaran, karena pada umumnya media pembelajaran yang dibahas adalah media pembelajaran berbasis IT"

Dari pemaparan di atas dapat disimpulkan bahwa penerapan model pembelajaran berbasis riset modifikasi IRC3 pada mahasiswa PAI semester IV dalam mata kuliah media pembelajaran mendapatkan tanggapan positif. Sebab penerapan pembelajaran ini mampu melatih dan meningkatkan sikap mandiri mahasiswa dalam belajar, mengkaji informasi, berkreasi dan berinovasi. Selain itu, melatih mahasiswa dalam membiasakan budaya literasi dan melakukan penelitian ilmiah. Lebih lanjut, penerapan pembelajaran ini juga mampu melatih mahasiswa untuk berbicara di depan umum, dan mempertanggungjawabkan hasil kajiannya masing-masing.

Namun disisi lain, semua mahasiswa berpendapat bahwa model pembelajaran berbasis riset modifikasi IRC3 ini sangat membutuhkan waktu yang 
panjang, sehingga perlu manajemen waktu selama proses pelaksanaannya. Selain itu, semua mahasiswa juga berpendapat untuk tetap mempertahankan penerapan model pembelajaran berbasis riset modifikasi IRC3 dalam proses pembelajaran mata kuliah media pembelajaran dengan sara manajemen waktu yang perlu ditingkatkan.

Dari Uraian di atas, dapat disimpulkan bahwa penerapan model pembelajaran berbasis riset modifikasi IRC3 mendapat tanggapan positif dari seluruh mahasiswa. Model pembelajaran ini sangat baik diterapkan apalagi dalam ruang lingkup proses pembelajaran di Perguruan Tinggi, khususnya di IAI Al Mawaddah Warrahmah Kolaka untuk memberikan pengalaman belajar yang bermakna dan menghasilkan outpun mahasiswa yang mampu berpikir kritis, ilmiah, kreatif dan inovatif. Namun dengan catatan penting yaitu manajemen waktu yang harus lebih diperhatikan. Sebab pada dasarnya model pembelajaran ini sangat memerlukan waktu yang banyak.

\section{KESIMPULAN}

Dari hasil penelitian ini maka dapat disimpulkan bahwa: (1) tahap proses pembelajaran berbasis riset modifikasi IRC3 yang diterapkan di IAI Al Mawaddah Warrahmah Kolaka dilakukan dengan 5 Langkah yaitu: (Introduce,
Review, Compare, Conclusion, Creative),

(2) penerapan model pembelajaran berbasis riset modifikasi IRC3mendapat tanggapan positif dari seluruh mahasiswa. Namun dengan catatan penting yaitu manajemen waktu yang harus lebih diperhatikan. Sebab pada dasarnya model pembelajaran ini sangat memerlukan waktu yang banyak.

\section{DAFTAR PUSTAKA}

Echols, John M, Hassan Shadily. (1996). Kamus Inggris Indonesia. Jakarta: PT Gramedia Pustaka Utama.

Kudrat, Masri Umar,dkk. (2011). Pengembangan pembelajaran berbasis riset di Program Studi Pendidikan Fisika FMIPA Universitas Negeri Gorontalo (Laporan Penelitian). Universitas Negeri Gorontalo. Gorontalo

Tim Penyusun. (2010). Pedoman Umum Pembelajaran Berbasis Riset. Yogyakarta: Universitas Gadjah Mada.

Philip G. Altbach, Jamil Salmi. (2011).

The Road to Academic Excellence. Jakarta: Salemba Humanika.

Saide, Duwana, Nur Thahirah Umajjah. (2018). "Perguruan Tinggi Islam Berbasis Riset Menyongsong Bonus Demografi Indonesia 2045", Al-Hikmah: Jurnal Dakwah, Vol. 12 No. 1, Tahun 2018, [Pp. 117-130]. 
Modifikasi Irc3 (Introduce, Review, Compare, Conclusion, Creative) di IAI Al-Mawaddah Warrahmah Kolaka

Sanjaya, W. (2011). Strategi Pembelajaran

Berorientasi Standar Proses

Pendidikan. Jakarta: Kencana

Prenada Media. 